\title{
A strategy action from the Cievs/Pernambuco in response to the emergency on Congenital Syndrome associated to Zika virus infection: an integrative action
}

\author{
Suzanne Santos de Lima 1 \\ Maria Auxiliadora Vieira Caldas Sivini 2 \\ Rita de Cássia de Oliveira 3 \\ Patrícia Michelly Santos Lima 4 \\ Bárbara Araújo Silva de Azevedo 5 \\ Camila Costa Dias 6 \\ Anna Samonne Amaral Lopes 7 \\ Priscilla Muniz Torres 8 \\ Romildo Siqueira Assunção 9 \\ Patrícia Ismael de Carvalho 10 \\ Luciana Caroline Albuquerque 11
}

1-11 Centro de Informações Estratégicas de Vigilância em Saúde de Pernambuco. Secretaria Estadual de Saúde de Pernambuco. Rua Dona Maria Augusta Nogueira, 519. Bongi. Recife, PE, Brasil. CEP: 50751-530. E-mail: suzanne-lima@hotmail.com

\begin{abstract}
Objectives: to describe the strategy action from the Centro de Informações Estratégicas de Vigilância em Saúde (Cievs/PE) (Strategic Information on Health Surveillance Center) in response to the emergency on Congenital Syndrome associated to Zika virus infection (CSZ) in Pernambuco State between 2015 and 2016.

Methods: description performed on the strategies and activities developed by Cievs/PE during the important international public health emergency related to CSZ.

Results: participated in detecting suspected CSZ cases; participated in elaborating clinical epidemiological protocols; developed electronic forms to notify CSZ cases and pregnant women with exanthema rashes; prepared epidemiological reports; developed a website about the emergency on the Cievs/PE website; insert the occurrence in the Comitê de Avaliação e Monitoramento de Eventos (CAME) (Committee to Assess and Monitor Occurrence); resolution of demands during readiness; technical visits from National and International institutions. The actions developed by the Cievs/PE were fundamental in detecting and following-up on 2,073 CSZ cases. 390 cases were confirmed (18.1\%) and 1,413 were discarded (65.6\%), and 4,467 pregnant women had exanthema rash.

Conclusions: the action from the Cievs/PE allowed to employ timely strategies on preparation and response in a qualified and cooperative way to face public health emergency on CSZ's

Key words Anti-emergency response capacity, Microcephaly, Zika virus
\end{abstract}




\section{Introduction}

Pernambuco State, located in the Northeast of Brazil, was the first State to identify the changes in the pattern of children being born with microcephaly, an occurrence that after culminated stated an important international public health emergency. ${ }^{1}$ The detection of the occurrence was in October 2015, when health professionals from the State public health network observed and reported to the Secretaria Estadual de Saúde de Pernambuco (SES/PE) (State Health Department in Pernambuco) the increased cases of newborns with microcephaly potentially associated to infectious causes.

The available data in the Sistema de Informação sobre Nascidos Vivos (Sinasc) (Information System on Live Births) corroborated with the observation of medical assistance in the health network. The data in this system demonstrated an increase of births with this congenital alteration, in 2011 to 2014 there were 9 cases and between August and September, 2015 there were 22 cases. ${ }^{2}$

Due to this increase, on October 27, 2015, the SES/PE issued a technical report warning the State health network on the possible alteration on the epidemiological standard of newborns with microcephaly, establishing an immediate notification of suspected cases through the Centro de Informações Estratégicas de Vigilância em Saúde (Cievs/PE) (Strategic Information on Health Surveillance Center), responsible for monitoring the occurrence statewide. ${ }^{3}$ In the same month, Pernambuco State officials notified this change in the epidemiological pattern to the Secretaria de Vigilância em Saúde (SVS) (Secretary on Health Surveillance) of the Ministério da Saúde (MS) (Ministry of Health).

The MS initiated a nationwide investigation detecting an increase of the cases in other States, especially in the Northeast region. ${ }^{4}$ On November 11, 2015, the Brazilian government declared an important national public health emergency and on November $28^{\text {th }}$ the relationship between Zika virus infection and microcephaly outbreak was confirmed.5,6 On November 29, 2015, Pernambuco officials also decreed an important public health emergency in the State. ${ }^{7}$

In the early 2016, considering the occurrence of similar cases in other countries, the World Health Organization (WHO) declared an important international public health emergency on microcephaly and other neurological abnormalities related to the Zika virus. ${ }^{2}$ This statement aimed to minimize the effects of the occurrence in the affected countries, located mainly in the Americas, highlighting Brazil, and reducing the risk of international spread. 8 It is noteworthy with the advanced knowledge on this occurrence currently called Congenital Syndrome associated to Zika virus infection (CSZ), it is due to the innumerable congenital abnormalities that Zika virus infection can cause. ${ }^{8}$

Globally, Brazil accumulated the largest number of cases. ${ }^{9}$ Pernambuco State had the highest $(20.8 \%)$ concentration of cases nationwide in the period of 2015 to 2016.10 In relation to this scenario, Pernambuco officials structured health surveillance actions, assistance network and diagnostic support to detect and follow-up on newborns with CSZ and pregnant women with exanthema rash, the latter was the purpose for intrauterine detection in suspected cases. 11,12

In the State, the performance of the Cievs/PE was fundamental to detect cases, monitoring and responding this event was the focal point and performing health surveillance actions. The Cievs/PE was founded in 2009 in order to contemplate the precepts established in the Regulamento Sanitário Internacional (RSI) (International Health Regulation) in 2005 and to integrate the Rede Nacional de Alerta e Resposta as Emergências em Saúde Pública (National Network Alert and Response to Public Health Emergencies).13-15 The main objectives of the center include to detect, verify, monitor, response and support technical areas, cities and towns and health regions for diseases with high potential dissemination and/or risks to the public health.15,16 In addition, it acts to monitor mass occurrence and natural and anthropogenic disasters in the state. 16

To detect and timely respond to possible important occurrence in the public health, the Cievs/PE system works round the clock including weekends and holidays. ${ }^{16}$ In addition, the center provides permanent communication facilities, including a website that allows immediate notification and disseminates technical and scientific information related to the occurrence. 16

Aiming to contribute the strengthening of the health surveillance, and considering that the actions developed by Pernambuco State officials subsidized conducts within National and International levels. This present study aimed to share the strategy action from Cievs/PE in response to the emergency Congenital Syndrome associated to Zika virus infection in the period of 2015 and 2016. 
Intersectoral actions developed during the CSZ emergency

Since Cievs/PE was founded, it has played a fundamental key role in detecting and coping with the public health emergencies in State, and has been the central structure of epidemiological surveillance in the occurrence of as the H1N1 influenza pandemic (2009), floods that occurred in the forest zone in Pernambuco (2010 and 2011), measles outbreak (2013) and mass events, such as the Confederation Cup in 2013 and FIFA World Cup in 2014. The Cievs/PE performance during these events allowed the creation and the improvement of pioneer instruments to detect and monitor, and integrate in several areas contributing to the operational management in public health events.

Since the identification of microcephaly cases in Pernambuco, in October of 2015, there was a need to establish criteria to detect microcephaly in newborns and to define the flow to attend, diagnose, surveillance and follow-up the cases with this congenital abnormality. In view of this need, Pernambuco State created along with the contribution of several professionals and health institutions, the Protocolo Clínico e Epidemiológico de Microcefalia (Clinical and Epidemiological Protocol for Microcephaly), the first version was published on October 10, 2015 and the second one on December 2 in the same year. The contribution from Cievs/PE was fundamental in the construction of the content and the graphical creation of this instrument.11,12 It is noteworthy that the versions of these protocols were pioneers in a global level in surveillance structure and healthcare for CSZ cases, and subsidized the creation of similar instruments in National and International levels. ${ }^{17}$

At the beginning of the CSZ emergency, the Cievs/PE participated to perform researches developed by the Programa de Treinamento em Epidemiologia Aplicada aos Serviços do SUS (EpiSUS) (Training Program in Epidemiology Applied to the Public Health System (SUS) Services), linked to the MS. This research was made possible to characterize the first cases of microcephaly related to Zika virus reported in the metropolitan region of Recife, in Pernambuco. ${ }^{18}$

Due to the high number of cases notified in the State, the SES/PE carried out seven task forces for children suspected of CSZ. These task forces counted on professionals from the epidemiological surveillance, among them, the Cievs/PE analysts, neurologists, pediatricians, ophthalmologists and geneticists. These professionals assisted 652 children and contributed to confirm 50 cases and discarded 592.

Detection of Congenital Syndrome cases associated to Zika virus infection

Among the activities from the Cievs/PE, there is an online communication of Doenças de Notificação Compulsória Imediata (DNCI) (Immediate Notification of Compulsory Diseases) through electronic forms and notification by telephone and email, making real-time communication of the cases, subsidizing health officials to response on the occurrence. 16 Therefore, since the observation of the health network regarding to the increase of microcephaly cases and the fact of an inexistence official system to notify the cases, The Cievs/PE elaborated two electronic forms for CSZ notification available on its website.

The first form prevailed from October $26^{\text {th }}$ to December 1, 2015. With the publication of the second version of the microcephaly protocol on December 2, 2015, a new form was developed, adapting some variables to the new established criteria to notify the cases. In addition, the second version of the protocol established an immediate notification on pregnant women with exanthema rash and a specific electronic form was created for this purpose. 12 These forms had 2,073 suspected CSZ cases and 4,498 pregnant women with exanthema rash.

Besides detecting cases, the center managed the databases with duplicities and inconsistencies analysis and classified the cases according to the growth curves and the development recommended by WHO. The information produced by the Cievs/PE served as a basis for the actions developed by the Public Health Sysytem (SUS) and subsidized several scientific studies in order to improve the knowledge on this occurrence.

\section{Monitoring of CSZ cases}

The notified cases were monitored by the Cievs/PE, and they were responsible for the confluence and consolidation of the data through a weekly flow of information on the follow-up of the cases carried out by the primary care, the Gerencias Regionais de Saúde (GERES) (Regional Health Management), the Serviço de Verificação de Óbito (SVO) (Death Surveillance Service), the reference care units for children suspected of CSZ, the Centro de Informações Estratégicas de Vigilância em Saúde municipais - Recife e Jaboatão dos Guararapes (Strategic Information Center on Health Surveillance 
in Recife and Jaboatão dos Guararapes Cities), Laboratório Central de Saúde Pública de Pernambuco (Lacen-PE) (Central Laboratory for Public Health in Pernambuco) and Instituto Aggeu Magalhães (IAM) (Aggeu Magalhães Institute).

To monitor the occurrence by the state health surveillance, the Cievs/PE developed two monitoring panels with the objective to obtain quick and systematic information. These panels contained descriptive information and statistical analyzes on the cases, contributing for the elaboration of epidemiological reports and availability of data in response to the information demands, including by the press.

An important monitoring strategy was the inclusion of the emergency in public health in the Comitê de Avaliação e Monitoramento dos Eventos de Saúde Pública (CAME) (Committee to Assess and Monitor Public Health Occurrence), under the coordination of the Cievs/PE. This committee meets weekly and participates in several areas of the State health surveillance. The occurrence was the main focus in the CAME meetings for 47 epidemiological weeks, contributing to monitor, assess and propose strategies to deal with the emergencies.

\section{Dissemination of information on the occurrence}

Due to the magnitude and the scope of the occurrence, and for the fact that Pernambuco State is an important territory in terms of detecting the first cases and the high number, the demand for the information has become a necessity of the other federative units, population, scientific communities, public organs and National and International media.1,10 Given this scenario, the Cievs/PE developed several instruments and means to disseminate information about this public health emergency.

With the objective in having free and periodic information available, the Cievs/PE began to produce a weekly epidemiological reports, resulting in the production of 98 reports on microcephaly and/or other alterations of the central nervous system and 48 of the pregnant women with exanthema rash, containing descriptive and spatial analysis of the cases. The data from these reports subsidized the construction of the bulletins of the Pan American Health Organization (PAHO). ${ }^{19}$

An innovative strategy that obtained a significant commitment was the creation of the electronic page on this public health emergency in the Cievs/PE site. The electronic page was an important instrument to notify the cases, disseminate epidemiological reports, notes and technical protocols and other scientific publications on the subject. Since October 2015, when the electronic page was created until December 2016, there were 32,775 accesses, corresponding to $36.6 \%$ of the views on the site. The electronic page obtained an average/month of 2,185 accesses, registering the maximum of views $(13,351)$ in November 2015.20 Despite the great concentration of accesses occurred in Brazil, the electronic page registered entries from all continents and several countries, mainly from the United States, Paraguay and Germany. 20

The center was also the focal point for the Ministry of Health during the emergency, therefore a flow of systematized information about the event was established by the National Cievs, initially with a daily flow and later weekly. This information subsidized the Centro de Operações de Emergência em Saúde Pública - Microcefalia (COES Microcefalia) (Operational Emergency Center in Public Health-Microcephaly), established at a federal level.

The CSZ cases and the pregnant women with exanthema rash were monitored and followed-up by various public organs and institutions. This way, the Cievs/PE was responsible for sending information and the databases on the cases, with the aim of aligning the information worked by various agents and guaranteed their trustworthiness. So, a weekly flow of information was sent from the Cievs/PE to the Núcleo de Apoio a Família de Crianças com Microcefalia (Support Center for Family of Children with Microcephaly), Secretaria Executiva de Regulação em Saúde e de Atenção à Saúde (Executive Secretary of Health Regulation and Care), Programa Mãe Coruja Pernambucana (Owl Mother Program in Pernambuco), IAM, setor de imprensa da SES/PE (the Press sector at SES/PE), Coordenação Estadual de Atenção à Pessoa com Deficiência (State Coordination Care on People with Deficiency), Coordenação Estadual de Saúde da Mulher (State Coordination on Women's Health), GERES and the Cievs from Recife and Jaboatão dos Guararapes cities.

Other actions taken by the Cievs/PE during the CSZ public health emergency

The pioneer work developed by the epidemiological surveillance in Pernambuco State, in which the Cievs/PE was a central structure to face of this unusual occurrence of great magnitude, aroused the interest of several National and International institutions. As a result, during the period of 2015 to 2016, 
the Cievs/PE was visited by the Centers for Disease Control and Prevention (CDC), PAHO, the Ministry of Health and Secretary of State Health Departments from Alagoas, Minas Gerais, Goiás, Paraíba and Rio Grande do Norte.

The Cievs/PE readiness during this public health emergency was a strategy that ensured technical team, media and inputs in an uninterrupted manner, ensuring timely detection and response to notify the cases and demands related to the occurrence. The total readiness of the task forces, $78 \%$ were emergency-related demands, requiring intersectoral and inter-institutional coordination. Most $(60 \%)$ of the task forces occurred during the weekend, $27 \%$ on the holidays and $13 \%$ during the weekly night time period. In summary, the actions developed by the Cievs/PE with the support of several agents, contributed to confirm 390 (18.1\%) CSZ cases and

\section{References}

1. Brasil. Ministério da Saúde. Protocolo de vigilância e resposta à ocorrência de microcefalia e/ou alterações do sistema nervoso central (SNC). 2 ed. Brasília; 2015.

2. Pernambuco. Secretaria Estadual de Saúde. Secretaria Executiva de Vigilância em Saúde. Boletim Anual da Secretaria Executiva de Vigilância em Saúde. Pernambuco; 2016

3. Pernambuco.Secretaria Estadual de Saúde. Secretaria Executiva de Vigilância em Saúde de Pernambuco. Nota Técnica SEVS/DGCDA Nº43, 27 de outubro de 2015 Possível Alteração do padrão de ocorrência de microcefalia (Anomalia Congênita) em nascidos no Estado de Pernambuco. Pernambuco, 2015. [acesso em: 09 jan. 2018] Disponível em: www.cievspe.com

4. Souza WV, Araújo TVB, Albuquerque MFPM, Braga MC, Ximenes RAA, Miranda-Filho DB, Bezerra LCA, Dimech GS, Carvalho PI, Assunção RS, Santos RH, Oliveira WK, Rodrigues LC, Martelli CMT. Microcefalia no Estado de Pernambuco, Brasil: características epidemiológicas e avaliação da acurácia diagnóstica dos pontos de corte adotados para notificação de caso. Cad Saúde Pública. 2016; 32 (4): e00017216.

5. Brasil. Ministério da Saúde. Portal da Saúde. Ministério da Saúde confirma relação entre vírus Zika e microcefalia [Internet]. Brasília, DF; 2015 [acesso em 18 jan 2017]. Disponível em: http://portalsaude.saude.gov.br/index.php /cidadao/principal/agencia-saude/21014-ministerio-dasaude-confirma-relacao-entre-virus-zika-e-microcefalia

6. Brasil. Ministério da Saúde. Portaria No 1.813 , de 11 de novembro de 2015. Declara Emergência em Saúde Pública de importância Nacional (ESPIN) por alteração do padrão de ocorrência de microcefalias no Brasil. Diário Oficial da República Federativa do Brasil [Internet]. Brasília (DF), 2015 nov 12. Seção 1. p. 51, 2015. [citado 2017 Jan 17]. Disponível em: http://pesquisa.in.gov.br/imprensa/jsp/visualiza/index.jsp?jornal $=1$ \&pagina $=51 \&$ data $=12 / 11 / 2015$ discarded 1,413 (65.6\%) in Pernambuco State.

The experience of the Cievs/PE in the CSZ emergency was made possible to support the development of knowledge, policies and strategies, thus, reaffirming is a relevant strategy for the health surveillance to strengthen the warning and respond to the Public Health System (SUS) capacity to face public health emergencies. However, the Cievs needs to be strengthened as a strategy to learn continuously through their experience and relationship with their partners.

Lastly, the Cievs/PE performance in this occurrence enabled the use of timely readiness and respond to strategies in a qualified and cooperative manner. This experience can subsidize other institutions and services of the health surveillance to face public health emergencies.
7. Pernambuco. Governo do Estado de Pernambuco. Decreto $\mathrm{n}^{\circ}$ 42.438, de 29 de novembro de 2015. Diário Oficial do Estado de Pernambuco [Internet]. Recife, $2015 \mathrm{dez}$ 01, p. 5. [citado 2016 Nov 23]. Disponível em: http://200.238.101.22/docreader/docreader.aspx?bib=20151 $201 \&$ pasta $=$ Dezembro $\backslash$ Dia\%2001

8. WHO (World Health Organization). Zika strategic response plan quarterly update: julho-setembro 2016. 2016; 29. [acesso em 05 jan 2018]. Disponível em: http://apps.who.int/iris/bitstream/10665/250626/1/WHOZIKV-SRF-16.4-eng.pdf?ua=1

9. WHO (World Health Organization). Situation report: zika virus, microcephaly, guillain-barré syndrome: 15 december 2016. Genebra: 2016. [acesso em 05 jan 2018]. Disponível em: http://apps.who.int/iris/bitstream/10665/252533/1/zika sitrep15Dec2016-eng.pdf?ua=1

10. Brasil. Ministério da Saúde. Informe epidemiológico $\mathrm{N}^{\mathrm{o}} 57$ - semana epidemiológica (SE) 52/2016 (25 a 31/12/2016) monitoramento dos casos de microcefalia no Brasil. 2017.

11. Pernambuco. Secretaria Estadual de Saúde. Secretaria Executiva de Vigilância em Saúde de Pernambuco. Protocolo clínico e epidemiológico para investigação de casos de microcefalia. Versão ${ }^{\circ} 1$. Recife, 2015.

12. Pernambuco. Secretaria Estadual de Saúde. Secretaria Executiva de Vigilância em Saúde de Pernambuco. Protocolo clínico e epidemiológico para investigação de casos de microcefalia. Versão $n^{\circ} 2$. Recife, 2015.

13. Brasil.Agência Nacional de Vigilância Sanitária. Regulamento Sanitário Internacional RSI - 2005. Versão em português aprovada pelo Congresso Nacional por meio do Decreto Legislativo 395/2009 publicado no Diário Oficial [da] República Federativa do Brasil de 10/07/09, pág.11. 1 ed. Brasília, DF: Anvisa; 2010.

14. Brasil. Ministério da Saúde. Rede nacional de alerta e resposta às emergências em saúde pública [Internet] 2016 Ago 16. [acesso em 23 nov 2016]. Disponível em: 
http://portalsaude.saude.gov.br/index.php/oministerio/principal/leia-mais-o-ministerio/1313-secretariasvs/cievs-centro-de-informacoes-estrategicas-e-respostaem-vigilancia-em-saude/25191-rede-nacional-de-alerta-eresposta-as-emergencias-em-saude-publica

15. Pernambuco. Governo do Estado de Pernambuco. Portaria $\mathrm{N}^{\circ} 493$, de 06 de julho de 2009. Diário Oficial do Estado de Pernambuco [Internet]. 2009 jul 07. Saúde. p. 10-11. Recife, 2009. [acesso em 23 nov 2016]. Disponível em: http://200.238.101.22/docreader/docreader.aspx?bib=2009 \&pasta $=$ Julho $\backslash$ Dia $\% 2007$

16. Pernambuco. Governo do Estado de Pernambuco. Portaria $\mathrm{N}^{\circ}$ 564, de 26 de dezembro de 2014. Diário Oficial do Estado de Pernambuco [Internet]. 2014 dez 27. Saúde. p. 89. Recife, 2014. [acesso em 23 nov 2016]. Disponível em: http://200.238.101.22/docreader/docreader.aspx?bib=20141 227\&pasta $=$ Dezembro $\backslash$ Dia $\% 2027$

17. Embresa Brasil de Comunicação/ Agência Brasil. Microcefalia: protocolo de Pernambuco pode ser usado no mundo, diz OMS. [Internet]. Recife. 2016. [acesso em 09 jan 2018]. Disponível em: http://agenciabrasil.ebc.com.br/ geral/noticia/2016-02/microcefalia-protocolo-de-pernambuco-sera-usado-no-mundo-diz-diretora-da-oms
18. Vargas A, Saad E, et al. Características dos primeiros casos de microcefalia possivelmente relacionados ao vírus Zika notificados na Região Metropolitana de Recife, Pernambuco. Epidemiol Serv Saúde. 2016; 25: (4) 691-700.

19. OMS/OPAS (Organização Mundial da Saúde. Organização Panamericana de Saúde). Boletim Semana \#2: Resposta da Representação da OPAS/OMS no Brasil para a epidemia do vírus da zika e suas consequências. 2016. [acesso em 05 jan 2018]. Disponível em: http://www.paho.org/bra/images/ stories/SalaZika/boletim\%20semanal\%20 2\%20opas.pdf?u $\mathrm{a}=1$

20. Google Analytics [homepage na internet]. Comportamento. [acesso em 20 jan 2017]. Disponível em: http://analytics.google.com

Received on April 10, 2017

Final version presented on January 23, 2018

Approved on March 1, 2018 